\title{
EFEKTIFITAS KOMPRES DINGIN DAN HANGAT PADA PENATALEKSANAAN DEMAM
}

\author{
Nurlaili Susanti \\ Fakultas Sains dan Teknologi, UIN Maliki Malang \\ email :dr.santie@gmail.com
}

\begin{abstract}
Fever is a symptom that accompanies some infectious and non infectious diseases. Fever cause metabolic consequences such as dehydration, increasing oxygen consumption and metabolic rate. Treatment of fever can reduce patient discomfort and another symptoms such as fatigue, myalgia, diaphoresis and chills.In addition to antipyretic, the use of physical methods to reduce fever has been widely applied. Physical methods of cooling are the treatment of choice for hyperthermia, but their value in the treatment of fever remains uncertain. Fever treated with tepid-water sponging and combined with antipyretic drugs are more effectively than those treated with antipyretic drugs alone. Tepid-water sponging represents a simple, nonsedating method to combat the metabolic impact of shivering and to induce cutaneous vasodilatation that increases heat loss.
\end{abstract}

\section{PENDAHULUAN}

Demam diartikan sebagai respon fisiologis tubuh terhadap penyakit yang di perantarai oleh sitokin dan ditandai dengan peningkatan suhu pusat tubuh dan aktivitas kompleks imun. Demam merupakan gejala yang menyertai beberapa penyakit infeksi maupun penyakit radang non infeksi. Pada penyakit infeksi, demam dapat diakibatkan oleh infeksi virus yang bersifat self limited maupun infeksi bakteri, parasit, dan jamur. Demam dapat juga disebabkan oleh paparan panas yang berlebihan (overhating), dehidrasi atau kekurangan cairan, alergi maupun karena gangguan sistem imun.

Gejala demam dapat dipastikan dari pemeriksaan suhu tubuh yang lebih tinggi dari rentang normal. Dikatakan demam, apabila pada pengukuran suhu rektal $>38^{\circ} \mathrm{C}\left(100,4^{\circ} \mathrm{F}\right)$ atau suhu oral $>37,8^{\circ} \mathrm{C}$ atau suhu aksila $>37,2^{\circ} \mathrm{C}$ $\left(99^{\circ} \mathrm{F}\right)$. Sedangkan pada bayi berumur kurang dari 3 bulan, dikatakan demam apabila suhu rektal $>38^{\circ} \mathrm{C}$ dan pada bayi usia lebih dari 3 bulan apabila suhu aksila dan oral lebih dari $38,3^{\circ} \mathrm{C}$.

Penatalaksanaan demam sangat bermanfaat untuk mengurangi rasa tidak nyaman yang dirasakan pasien. Selain 
terapi simptomatis dan kausatif dengan menggunakan obat-obatan, demam dapat diturunkan dengan kompres kulit. Telah dikenal dua macam cara kompres kulit, yaitu kompres dingin dan kompres hangat. Kompres dingin telah dikenal secara luas penggunaannya di masyarakat dibandingkan kompres hangat. Tulisan ini akan mencoba mengulas efektifitas pemakaian kompres dingin dan hangat. Penjelasan yang mengacu pada proses fisiologis yang terjadi pada pemakaian kompres diharapkan dapat memberikan gambaran mengenai efektifitas pemakaian kompres dingin dan hangat pada penatalaksanaan demam.

\section{Temperatur Normal Tubuh}

Temperatur tubuh bervariasi setiap saat pada suatu rentang normal yang dikontrol oleh pusat termoregulasi yang berlokasi di hipotalamus. Tubuh secara normal mampu mempertahankan temperatur karena pusat termoregulasi hipotalamus menyeimbangkan produksi panas berlebih yang dihasilkan dari aktivitas metabolisme di otot dan hepar dengan kehilangan panas dari kulit dan paru.
Individu normal, rata-rata temperatur oral untuk usia 18-40 tahun adalah $36,8 \pm 0,4{ }^{\circ} \mathrm{C}\left(98,2 \pm 0,7{ }^{\circ} \mathrm{F}\right)$ dengan level terendah pada pukul 6 pagi dan level tertinggi pada pukul $4(37,7$ $\left.{ }^{\circ} \mathrm{C} / 99,9{ }^{\circ} \mathrm{F}\right)-6\left(37,2{ }^{\circ} \mathrm{C} / 98,9{ }^{\circ} \mathrm{F}\right)$ sore. oleh karena itu, suhu pagi hari $>37,2^{\circ} \mathrm{C}$ $\left(98,9{ }^{\circ} \mathrm{F}\right)$ atau suhu sore hari $>37,7{ }^{\circ} \mathrm{C}$ $\left(99,9{ }^{\circ} \mathrm{F}\right)$ harus dipertimbangkan sebagai demam. Temperatur rektal secara umum lebih tinggi dari pada oral yaitu sekitar $0,6{ }^{\circ} \mathrm{C}\left(1,0{ }^{\circ} \mathrm{F}\right)$. Hal ini disebabkan karena adanya pernafasan dari mulut. Temperatur membran timpani lebih mendekati temperatur inti tubuh, tetapi pemeriksaannya lebih sulit. Tubuh senantiasa berupaya untuk mempertahankan set poin suhu pada kisaran $37^{\circ} \mathrm{C}$, dengan variasi sirkadian < $1^{\circ} \mathrm{C} \quad\left(36,3-37,2^{\circ} \mathrm{C}\right)$ pada pengukuran suhu aksila.

\section{Termoregulasi}

Tubuh memiliki mekanisme untuk mempertahankan suhu pada kondisi normal. Temperatur tubuh dikontrol oleh pusat termoregulasi dalam hipotalamus yang menerima input dari 2 set termoreseptor yaitu reseptor di hipotalamus sendiri yang memonitor temperatur darah yang melewati otak (temperature inti), dan 
Efektifitas Kompres Dingin dan Hangat ...

reseptor di kulit (khususnya di tubuh) yang memonitor temperatur eksternal. Kedua set informasi ini dibutuhkan agar tubuh dapat membuat penyesuaian yang tepat. Pusat termoregulasi mengirim impuls ke beberapa efektor yang berbeda untuk menyesuaikan temperatur tubuh. Termoregulasi masih belum berkembang dengan baik pada bayi baru lahir dan khususnya pada bayi prematur.

Pada suhu lingkungan yang selalu bervariasi, suhu tubuh secara normal dipertahankan pada rentang yang sempit yaitu berfluktuasi $0,5^{\circ} \mathrm{C}$ dibawah normal pada pagi hari dan $0,5^{\circ} \mathrm{C}$ diatas normal pada malam hari. Produksi panas dipengaruhi oleh aktivitas metabolik dan aktivitas fisik. Kehilangan panas terjadi melalui radiasi, evaporasi, konduksi dan konveksi. Dalam keadaan normal termostat di hipotalamus selalu diatur pada set point $\pm 37^{\circ} \mathrm{C}$, setelah informasi tentang suhu diolah di hipotalamus selanjutnya ditentukan pembentukan dan pengeluaran panas sesuai dengan perubahan set poin.

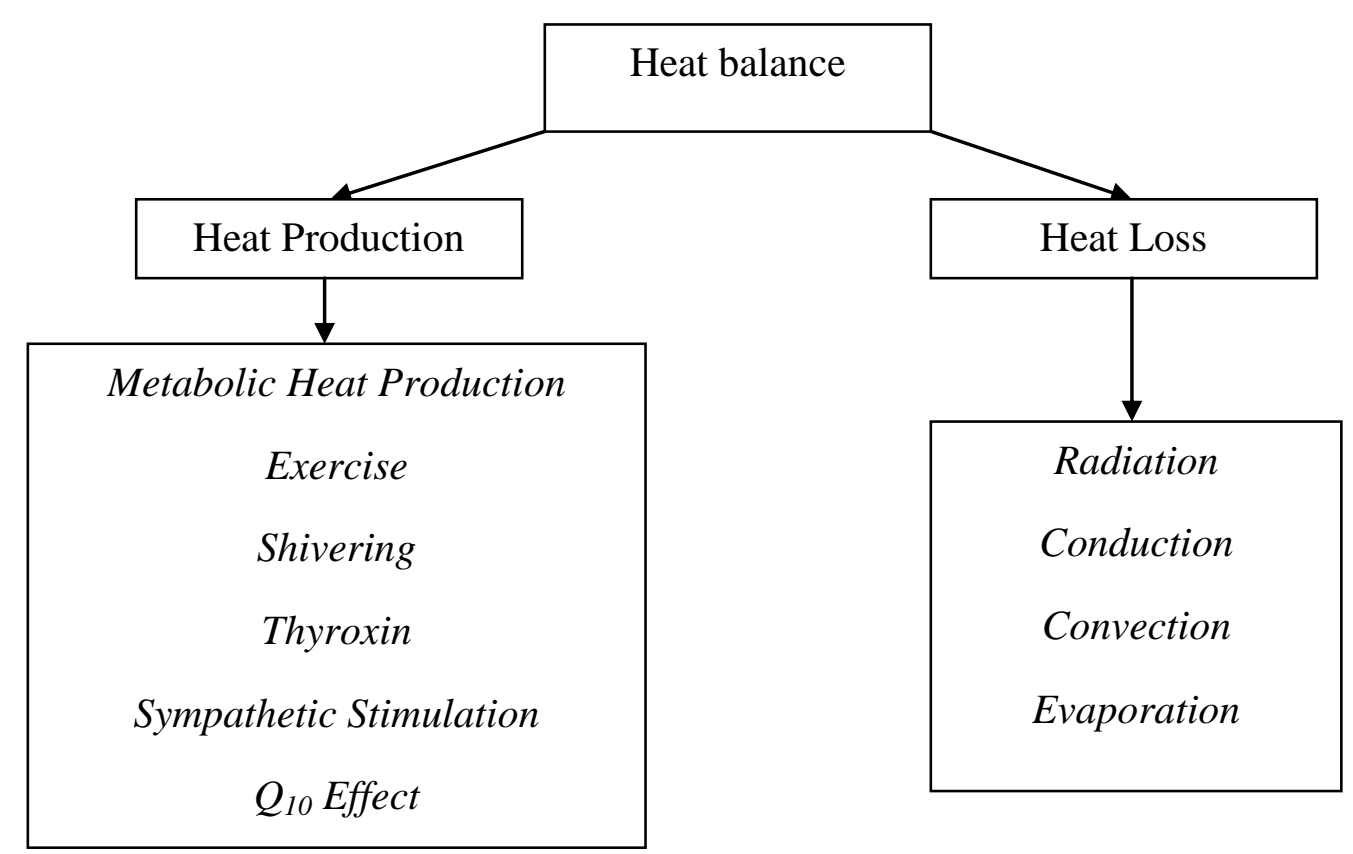

Gb. Pertukaran Panas antara tubuh dan lingkungan 
Hipotalamus posterior berperan meningkatkan produksi panas dan mengurangi pengeluaran panas. Bila suhu lingkungan lebih rendah dari suhu tubuh maka hipotalamus posterior merespon dengan meningkatkan produksi panas melalui peningkatan metabolisme dan aktivitas otot rangka dalam bentuk menggigil (shivering). Pengeluaran panas dikurangi dengan vasokontriksi pembuluh darah kulit dan mengurangi produksi keringat oleh kelenjar keringat. Sedangkan hipotalamus anterior berperan menurunkan suhu tubuh dengan cara mengeluarkan panas. Bila suhu lingkungan lebih tinggi dari suhu tubuh maka hipotalamus anterior merespon dengan meningkatkan pengeluaran panas melalui vasodilatasi kulit dan menambah produksi keringat.

\section{Patofisiologi Demam}

Peningkatan suhu tubuh terjadi akibat peningkatan set point. Infeksi bakteri menyebabkan demam karena endotoksin bakteri merangsang sel PMN untuk menghasilkan pirogen endogen yaitu interleukin-1, interleukin 6 atau TNF (tumor necrosis factor). Pirogen adalah substansi yang menyebabkan demam. Pirogen terdiri dari endogen dan eksogen. Pirogen eksogen adalah pirogen yang berasal dari luar tubuh terutama mikroba dan produknya seperti toksin. Contoh klasik dari pirogen eksogen adalah endotoksin lipopolisakarida yang diproduksi oleh semua bakteri gram negatif. Endotoksin adalah substansi poten yang tidak hanya sebagai pirogen tapi juga sebagai induser dari perubahan patologis yang bervariasi yang diobservasi pada infeksi Gram negatif. Grup lain dari substansi bakteri yang menjadi pirogen yang poten diproduksi oleh bakteri gram positif. Toksin dari TSS (Toxic Shock Syndrome / TSST-1) dihubungkan dengan strain Stafilokokus aureus yang diisolasi dari pasien dengan Toxic Shock Syndrome (TSS). TSST-1 dan enterotoksin lain dari S. aureus dan eksotoksin dari Streptokokus grup A bekerja sebagai toksin langsung tetapi juga berperan sebagai superantigen. Superantigen berperan dalam pathogenesis infeksi gram positif yang parah akibat interaksi dengan MHC (Major Histocompatibility Complex) II dan sejumlah sel $\mathrm{T}$ untuk melepaskan sitokin pirogenik. Seperti endotoksin dari bakteri Gram negatif, toksin yang diproduksi oleh Stafilokokus dan Streptokokus menyebabkan demam 
Efektifitas Kompres Dingin dan Hangat ...

pada percobaan hewan yang diinjeksi secara intravena dalam rentang submikrogram $/ \mathrm{kg}$.

Sitokin Pirogenik adalah pirogen endogen yang spesifik yang dilepaskan sebagai respon terhadap pirogen eksogen. Sitokin adalah protein kecil (BM 10-20.000 D) yang meregulasi proses imun, inflamasi dan hematopoietik. Sebagai contoh, stimulasi dari proliferasi limfosit selama respon imun vaksinasi adalah hasil dari sitokin yang bervariasi mencakup IL-2, IL-4, dan IL-6. sitokin yang disebut Granulocyte Colony Stimulating Factor (G-CSF) menstimulasi granulositopoiesis di sumsum tulang. Beberapa sitokin menyebabkan demam dan disebut sitokin pirogenik.

Ada beberapa sitokin pirogenik, yaitu IL-1, IL-6 TNF dan CNTF (neurotrophic factor). Interferon-alpha dapat juga dipertimbangkan sebagai sitokin pirogenik sejak memproduksi panas. pada faktanya, IL-1, IL-6, dan TNF masing-masing diinjeksikan ke manusia dan menghasilkan demam. IL1 dan TNF adalah pirogen yang utama, menghasilkan panas pada dosis rendah 10 ng/kg (IV atau SC). IL-6 juga merupakan pirogen tetapi membutuhkan dosis mikrogram/kg lebih dari nanogram $/ \mathrm{kg}$ dosis IL-6 dibutuhkan untuk memproduksi demam pada manusia. Meskipun demikian, sejumlah besar dari IL-6 bersirkulasi pada semua penyakit demam dan IL-6 yang diinduksi oleh IL-1 atau kombinasi IL-1 dan TNF dilaporkan secara klinis lebih sering terukur. Tikus tanpa gen yang mengkode IL-6 tidak menimbulkan demam selama infeksi bakteri. Jadi, pada kebanyakan penyakit infeksi dan inflamasi, konsentrasi rendah dari IL-1 dan TNF menginduksi sejumlah besar dari IL-6 dan inilah sebagai pencetus pusat di hipotalamus untuk mengontrol suhu tubuh.

Pirogen eksogen menginduksi sintesis dan pelepasan dari sitokin pirogenik endogen. Kebanyakan substansi pirogenik eksogen berasal dari bakteri dan jamur, sedangkan virus menginduksi sitokin pirogenik dengan menginfeksi sel. Demam juga dapat diakibatkan oleh berbagai jenis penyakit inflamasi, trauma atau kompleks antigen antibodi yang dapat menginduksi produksi IL-1,TNF, dan IL-6 yang merangsang hipotalamus untuk meningkatkan set point ke level demam. 
Pirogen endogen bekerja di hipotalamus dengan bantuan enzim siklooksigenase 2 (COX-2) membentuk prostaglandin E2. Hal ini menyebabkan peningkatan level prostaglandin E2 dari jaringan hipotalamus anterior dan ventrikel III dimana konsentrasi tertinggi berada di sekitar organ vasculosum lamina terminalis yang jaringan kapilernya meluas ke sekeliling pusat termoregulasi hipotalamus. Interaksi pirogen dengan endothelium pembuluh darah circumventricular hipotalamus adalah langkah awal untuk meningkatkan set point ke level demam. Sitokin pirogenik seperti IL-1, IL-6 dan TNF dilepaskan dari sel dan memasuki sirkulasi sistemik dan menginduksi sintesis PGE2 untuk mencetuskan demam. Sitokin pirogenik juga menginduksi pembentukan PGE2 di jaringan perifer. PGE2 di perifer dapat berkomunikasi dengan otak secara tidak langsung untuk meningkatkan set poin hipotalamus melalui beberapa cara, diantaranya dengan menstimulasi serabut saraf otonom dan melalui rute vagal yang merupakan cara terbaik. Peningkatan PGE2 di perifer juga menyebabkan myalgia non spesifik dan artralgia yang sering menyebabkan demam.
Demam memiliki tiga fase klinis yaitu menggigil (chill), febris (fever) dan kemerahan (flush). Pada fase menggigil, temperatur inti tubuh naik menjangkau set poin suhu baru dengan vasokonstriksi perifer untuk mengurangi pengeluaran panas dan peningkatan aktivitas otot (shivering) untuk meningkatkan produksi panas. Pada fase febris terjadi keseimbangan antara produksi dan kehilangan panas pada set poin yang meningkat. Kulit teraba hangat, kemerahan, dan kering. Ketika set poin kembali normal, tubuh mempersepsikan dirinya menjadi terlalu panas, sehingga mekanisme mengurangi panas dimulai melalui vasodilatasi perifer dan berkeringat (diaphoresis).

\section{Penatalaksanaan Demam}

Demam dihubungkan dengan konsekuensi metabolik potensial meliputi dehidrasi, peningkatan konsumsi oksigen, dan laju metabolisme. Untuk setiap peningkatan satu derajat diatas $37^{\circ} \mathrm{C}$ terjadi peningkatan konsumsi oksigen sebanyak $13 \%$. Hal ini dapat memperburuk insufisiensi paru dan jantung yang telah ada sebelumnya. Demam yang berkepanjangan dihubungkan dengan peningkatan 
kebutuhan nutrisi yang mungkin bermasalah jika pasien mengalami penurunan nutrisi. Demam berkepanjangan juga menyebabkan kelemahan.

Demam pada umumnya dihubungkan dengan infeksi virus yang bersifat self limited. Penggunaan obat penurun demam (antipiretik) dalam hal ini dapat mengurangi gejala sakit kepala, mialgia, dan arthralgia. Meskipun demam kemungkinan bermanfaat dalam meningkatkan pertahanan tubuh, tetapi perlu dipertimbangkan aspek kenyamanan pasien. Penurunan demam membantu mengurangi rasa tidak nyaman dan gejala penyerta seperti kelemahan, myalgia, diaphoresis dan menggigil. Terapi simptomatis demam tidak berbahaya dan tidak memperlambat penyembuhan infeksi bakteri maupun virus. Akan tetapi, ada situasi klinis dimana observasi terhadap demam memberi keuntungan diagnostik. Lama demam dan karakteristik naik turunnya dapat mengarahkan kecurigaan infeksi beberapa penyakit, seperti demam berdarah, demam thipoid, dll.

Secara umum demam terjadi akibat peningkatan produksi panas yang tidak diimbangi oleh pengeluaran panas tubuh. Oleh karena itu penatalaksanaan demam ditujukan untuk mengurangi produksi panas dan meningkatkan pengeluaran panas tubuh. Peningkatan pengeluaran panas tubuh dapat dilakukan dengan meningkatkan radiasi, konduksi, konveksi, dan evaporasi, diantaranya membuka pakaian atau selimut yang tebal dan ganti dengan pakaian tipis agar terjadi radiasi dan evaporasi. Meningkatkan aliran udara dengan meningkatkan ventilasi ke dalam rumah akan menyebabkan terjadinya mekanisme konveksi. Selain itu, dapat dilakukan upaya melebarkan pembuluh darah perifer dengan cara menyeka kulit dengan air hangat (tepidsponging) atau kompres hangat. Mendinginkan dengan air es atau alkohol kurang bermanfaat karena mengakibatkan vasokonstriksi pembuluh darah sehingga panas sulit disalurkan baik lewat mekanisme evaporasi maupun radiasi. Selain itu, pengompresan dengan alkohol dapat terserap oleh kulit dan terhirup pernafasan yang dapat menyebabkan keracunan alkohol dengan gejala hipoglikemia, koma sampai kematian. Agar kadar elektrolit tidak meningkat saat terjadi evaporasi, maka seseorang 
yang mengalami demam harus mengkonsumsi cairan yang cukup.

Penurunan produksi panas diantaranya dapat dilakukan dengan istirahat yang cukup agar laju metabolisme tubuh menurun. Pemberian terapi simptomatik demam dengan antipiretik seperti asetaminofen, aspirin atau abat anti inflamasi non steroid (NSAID) bekerja dengan menurunkan peningkatan set poin suhu di otak dengan menghambat enzim siklooksigenase (COX). Sintesis PGE2 bergantung pada enzim siklooksigenase. Penghambat COX, seperti NSAID, adalah antipiretik yang poten karena mengganggu perubahan asam arakhidonat menjadi prostaglandin. Asetaminofen, penghambat COX yang lemah di jaringan perifer, dioksidasi di otak oleh sitokrom P-450 dan menghambat aktivitas COX. PGE2 tidak berperan pada termoregulasi normal, berdasarkan pengamatan bahwa penggunaan aspirin atau NSAID secara kronis tidak menurunkan temperatur inti tubuh normal. Kortikosteroid juga merupakan antipiretik yang efektif yang menurunkan sintesis PGE2 dengan menghambat aktivitas fosfolipase A2, yang dibutuhkan untuk melepaskan asam arakhidonat dari membran.
Kortikosteroid juga bekerja dengan menghambat transkripsi mRNA untuk sitokin pirogenik.

$\begin{array}{rrr}\text { Intervensi } & \text { spesifik } & \text { dalam } \\ \text { penanganan } & \text { demam } & \text { adalah }\end{array}$
mengidentifikasi etilogi yang mendasari terjadinya demam pada seorang pasien. Misalnya demam akibat infeksi bakteri, maka terapi kausatif adalah dengan memberikan antibiotik. Sebelum didapatkan hasil kultur, pemberian terapi awal dengan antibiotik spektrum luas dianjurkan. Karena sekitar $70 \%$ penyebab demam tidak dapat diidentifikasi, maka pemakaian antibiotik awal berdasarkan pengetahuan mengenai spektrum anti mikroba dan resistensi antibiotik yang dimiliki instansi pelayanan kesehatan.

\section{Efektifitas Kompres Dingin dan Hangat Pada Penatalaksanaan Demam}

Telah lama dikenal pemakaian metode fisik dalam menurunkan demam. Metode fisik ini ditujukan untuk meningkatkan pengeluaran panas baik secara konduksi, konveksi, maupun evaporasi. Metode yang umum dipakai adalah kompres dingin. Akan tetapi, keuntungannya dalam terapi demam belum sepenuhnya dipahami. Kompres 
Efektifitas Kompres Dingin dan Hangat ...

dingin adalah terapi pilihan untuk hipertermia yang ditandai oleh temperatur inti tubuh melampaui set poin termoregulasi. Berbeda dengan demam, shivering, vasokonstriksi kulit dan respon yang berhubungan dengan perilaku meningkatkan temperatur inti untuk menjangkau peningkatan set poin suhu yang diakibatkan oleh kerja pirogen di pusat termoregulasi. Selama hipertermia, penurunan produksi panas, vasodilatasi, berkeringat dan respon perilaku bekerja untuk menurunkan temperatur tubuh. Jadi, pemakaian kompres dingin pada terapi hipertermia tidak bertentangan dengan proses yang ditimbulkan oleh pemakaian terapi yang lain.

Kompres dingin menurunkan temperatur kulit lebih cepat dari pada temperatur inti tubuh, sehingga merangsang vasokonstriksi dan shivering. Shivering mengakibatkan gangguan metabolisme karena meningkatkan konsumsi oksigen dan volume respirasi, meningkatkan persentase karbon dioksida dalam udara ekspirasi dan meningkatkan aktifitas sistem saraf simpatis. Oleh karena itu, kompres dingin kurang efektif dalam tatalaksana demam karena selain kurang nyaman juga merangsang produksi panas dan menghalangi pengeluaran panas tubuh.

Selain kompres dingin, dikenal pemakaian kompres hangat dalam tatalaksana demam. Kompres hangat adalah melapisi permukaan kulit dengan handuk yang telah dibasahi air hangat dengan temperatur maksimal $43^{\circ} \mathrm{C}$. Lokasi kulit tempat mengompres biasanya di wajah, leher, dan tangan. Kompres hangat pada kulit dapat menghambat shivering dan dampak metabolik yang ditimbulkannya. Selain itu, kompres hangat juga menginduksi vasodilatasi perifer, sehingga meningkatkan pengeluaran panas tubuh. Penelitian menunjukkan bahwa pemberian terapi demam kombinasi antara antipiretik dan kompres hangat lebih efektif dibandingkan antipiretik saja, selain itu juga mengurangi rasa tidak nyaman akibat gejala demam yang dirasakan. Pemakaian antipiretik dan kompres hangat memiliki proses yang tidak berlawanan dalam menurunkan temperatur tubuh. Oleh karena itu, pemakaian kombinasi keduanya dianjurkan pada tatalaksana demam.

\section{KESIMPULAN}

Dari penjelasan diatas, dapat ditarik kesimpulan bahwa pemakaian 
kompres dingin efektif untuk mengatasi hipertermia, karena dapat menurunkan temperature kulit dengan cepat. Akan tetapi tidak efektif untuk mengatasi demam karena memicu terjadinya vasokonstriksi dan shivering. Sedangkan pemakaian kompres hangat efektif untuk mengatasi demam memicu vasodilatasi yang dapat meningkatkan pengeluaran panas tubuh. Pemakaian kompres hangat dianjurkan sebagai terapi kombinasi dengan antipiretik untuk membantu menurunkan temperature tubuh.

\section{DAFTAR PUSTAKA}

Axelrod, Peter. 2000. External Cooling in the Management of Fever. Clinical Infectious Disease. Volume 31 (Suppl 5)

Bajhatia, Neeraj, et all. 2009. Metabolic Benefits of Surface Counter Warming during Therapeutic Temperature Modulation. Critical Care Medicine. Volume 37, Number 6 : 1893-1897.

Barone, James E. 2009. Fever : Fact and Fiction. The Journal of Trauma. Volume 67, Number 2 : 406409.

Boulant, Jack A. 2000. Role of the Preoptic-Anterior Hypothalamus in Thermoregulation and Fever. Clinical Infectious Disease. volume 31(suppl 5), page 157161.
Dalal, Shalini \& Zhukovsky, Donna S. 2006. Pathophysiology and Management of Fever. The Journal of Supportive Oncology. Volume 4, Number 1: 9-16.

Edwards, Helen E, et all. 2005. Fever Management Practice : What Paediatric Nurses Say. Nursing and Health Sciences. volume 3, Number 3 : 119-130.

Kayman H. 2003. Management of Fever: Making Evidence-based Decisions. Clinical Pediatrics. Volume 42, Number 383.

Kelly, Greg. 2006. Body Temperature Variability (Part 1): A Review of the History of Body Temperature and its Variability Due to Site Selection, Biological Rhythms, Fitness, and Aging. Alternative Medicine Review. Volume 11, Number 4. Page 278-293.

Porat, Reuven \& Dinarello, Charles A. 2004. Pathophysiology and Treatment of Fever in Adults, (Online), http://www.utdol.com/applicatio $\mathrm{n} /$ topic/print.asp? file=othr_inf $/ 16086$. Diakses tanggal 1 September 2011. 